\title{
Physico Chemical, Antioxidant and Pasting Properties of Pre-heated Purple Sweet Potato Flour
}

\author{
Siti Nurdjanah $^{1,}{ }^{*}$, Neti Yuliana $^{1}$, Sussi Astuti ${ }^{1}$, Jeri Hernanto ${ }^{1}$, Zukryandry Zukryandry ${ }^{2}$ \\ ${ }^{1}$ Department of Agriculture Product Technology, Faculty of Agriculture, University of Lampung, Bandar Lampung, Indonesia \\ ${ }^{2}$ Polytechnic Negeri Lampung, Bandar Lampung, Indonesia
}

\section{Email address:}

siti.nurdjanah@fp.unila.ac.id (S. Nurdjanah),neti.yuliana@fp.unila.ac.id (N. Yuliana), sussi.astuti@fp.unila.ac.id (S. Astuti), jerihernanto@yahoo.com (J. Hernanto), zukryandre@yahoo.com (Z.Zukryandry)

${ }^{*}$ Corresponding author

\section{To cite this article:}

Siti Nurdjanah, Neti Yuliana, Sussi Astuti, Jeri Hernanto, Zukryandry Zukryandry. Physico Chemical, Antioxidant and Pasting Properties of Pre-heated Purple Sweet Potato Flour. Journal of Food and Nutrition Sciences. Vol. 5, No. 4, 2017, pp. 140-146.

doi: $10.11648 /$ j.jfns.20170504.11

Received: February 24, 2017; Accepted: April 17, 2017; Published: June 3, 2017

\begin{abstract}
Purple sweet potatoes contain anthocyanins which could function as a natural food colorant, and an antioxidant. One of the problems in handling the fresh roots is their susceptibility during storage, and to extend their uses, fresh purple sweet potato could be processed into flour. However, during flouring process, the properties of the purple sweet potato may undergo some changes such as partial gelatinization of the starch and discolorization. Therefore, the purpose of this study was to investigate the effect of pre-heating treatment during flouring process on degree of gelatinization, the anthocyanin content, the antioxidant activity and the total phenolic content of heat treated purple sweet potato flour. Other objectives were to observed the changes in the starch properties such as rheological properties, granular appearance of the heat treated- purple sweet potato flour. Pre-heating treatment of purple sweet potato flour was prepared by heating grated purple sweet potato in a single rotary drum cooker at $90^{\circ} \mathrm{C}$ for $15,30,45,60$ and $75 \mathrm{~min}$, followed by drying in a cabinet dryer at $60^{\circ} \mathrm{C}$ for $8 \mathrm{~h}$. The results showed the longer pre-heating time at $90^{\circ} \mathrm{C}$ had caused increase in the degree of gelatinization, increase in total phenolic and anthocyanin retention. In addition, differences in gelatinization temperature, maximum viscosity, paste stability and retrogradation, and differences in scanning electron microscope (SEM) of granular appearance were also observed. The overall results indicated that pre-heating treatment can be used for modifying the physical, chemical and rheological properties to suit various applications and preserving functional properties of purple sweet potato flour.
\end{abstract}

Keywords: Anthocyanin, Antioxidant, Phenolic, Pre-heating Treatment, Purple Sweet Potato Flour, SEM

\section{Introduction}

Sweet potato (Ipomoea batatas (L.) Lam), a fairly droughttolerant crop, is widely grown throughout the world, primarily in the tropics and subtropics. In addition, it has various skin and flesh color from white to yellow, orange, light purple to deep purple. Sweet potato ranks the sixth most important crops after rice, wheat, potatoes, maize and cassava. Globally, the annual sweet potato production accounts up to more than 105 million metric tons [1]. In Indonesia, the trend with respect to utilization of sweet potato is changing from domestic consumption to use in various commercial products such as flour, starch, pectin, and dietary fiber [2]. Purple sweet potatoes (PSP) contain relatively high acylated anthocyanins, with mainly cyanidin or peonidin as the aglycone [3]. It is suggested that anthocyanins, as natural pigments, may provide beneficial health effects. Studies proved anthocyanin provide physiological functions such as antihyperglycemic [4], antiinflamatory and anticarcinogenic [5] and antioxidant [6].

Truong et al [7] reported the anthocyanin content of many purple-flesh sweet potato genotypes were between 0-210 $\mathrm{mg} / 100$ fresh weight. These contents were lower than those from black currant and blueberries $(322-476 \mathrm{mg} / \mathrm{fw})$, but comparable with those from grapes $(27-120 / 100 \mathrm{~g}$ fw), plum (19-124mg/100g fw), eggplant $(86 \mathrm{mg} / 100 \mathrm{~g} \mathrm{fw})$, and red radishes $(100 \mathrm{mg} / 100 \mathrm{~g} \mathrm{fw})$ as reported by Wu et al $[8 \mathrm{Wu}]$. 
Therefore many purple-flesh sweet potato genotypes fall in the middle of the spectrum of the high anthocyanin fruits and vegetables [7]. Anthocyanins form purple sweet potato has been known for its health effect. Kano et al. [9] reported anthocyanins from purple-fleshed sweet potato have shown a stronger free radical scavenging activity than those from red cabbage, grape skin, elderberry, purple corn and ascorbic acid.

In developing countries, sweet potatoes are often found to be rotten before they reach consumers due to improper storage conditions. Storage of fresh sweet potatoes require a controlled temperature $\left(13-15^{\circ} \mathrm{C}\right)$ and the relative humidity between $85-95 \%$ [10], those conditions are hard to achieved. One way to avoid losses due to improper handling, sweet potato can be converted into flour that has a longer shelf life and is ready for use.

Although anthocyanins from purple sweet are stable, transforming fresh purple sweet potato into flour may reduce the intensity of purple color of the flour. The discoloration of the flour could be caused by the degradation of anthocyanins due to peroxidase (POX) activity. POX is considered the major enzyme responsible for anthocyanin degradation in fruits and vegetables [11]. POX activity in purple sweet potato was higher than that found in purple corn cob (136 units/g dry basis, and 27 units/g dry basis respectively) [12].

In addition to discoloration of the flour, the use of purple sweet potato flour as raw material for various food products is still limited. This partly due to the fact that native starch is susceptible to high temperature, and extreme $\mathrm{pH}$ condition [13]. Therefore native starch content in purple sweet potato needs to be modified chemically or physically in order to widen the starch applications in various products and also to preserve anthocyanin from degradation. In this paper we reported study on physicochemical, functional, and rheological properties of physically modified purple sweet potato flour processed through pre-heating treatment.

\section{Materials and Methods}

\subsection{Materials}

Folin-Ciocalteu reagent and 2,2-diphenyl-1-picrylhydrazyl (DPPH) were obtained from Sigma (St. Louis, MO, USA), other reagents were purchased from commercial sources.

Local variety purple sweet potatoes (PSP), harvested 120 days after planting, were obtained from Seedling Farm, Agriculture Training Center Lampung.

\subsection{Preparation of Preheating Treatment of Purple Sweet Potato Flour}

Freshly harvested PSP were washed under running tap water and grated using a food chopper. The grated PSP was heated in a an electric oven equipped with a single rotary drum at $90^{\circ} \mathrm{C}$ for $0,15,30,45,60$, and 75 min depending on the treatment applied. The heated PSP were dried in an oven (Memmert) at $60^{\circ} \mathrm{C}$ for $8 \mathrm{hrs}$ to achieve moisture content of $10 \%$. The dry grated PSP was ground using a hammer mill (FCT Z500, Ramesia) and sieved to pass 80 mesh siever, stored in a sealed plastic bag until further analysis.

\subsection{Preparation of PSP Flour Extracts}

Samples of native PSP flour and preheated PSP flour (200 g) were macerated in $800 \mathrm{ml}$ of pure $96 \%$ ethanol for $24 \mathrm{~h}$ at $4^{\circ} \mathrm{C}$ in the dark room, then filtered through Whatman No. 42 filter paper. The remaining residues were washed with 400 $\mathrm{ml}$ of ethanol, both filtrates were collected as the crude extract filtrate. The ethanol in the crude extract was evaporated by the rotary evaporator $\left(0.1 \mathrm{MPa}, 40^{\circ} \mathrm{C}\right)$ until the volume was $500 \mathrm{~mL}$, kept in a dark brown bottle and stored at $-20^{\circ} \mathrm{C}$ until further analysis.

\subsection{Degree of Gelatinization}

The degree of gelatinization was determined using the amylose-iodine binding method according to Birch and Priestley [14] and Baks et al. [15] with minor modifications. A sample $(0.04 \mathrm{~g})$, freeze-dried, was dissolved in $50 \mathrm{ml}$ of $0.15 \mathrm{M} \mathrm{KOH}$ and the solution was mixed using a vortex for $15 \mathrm{~min}$. The solution was centrifuged (10 min, $3000 \mathrm{~g}$ ) using a Beckman centrifuge to remove the insoluble part of the sample. After centrifugation, $1 \mathrm{ml}$ of the supernatant was taken and neutralized with $9 \mathrm{ml} 0.017 \mathrm{M} \mathrm{HCl}$. Subsequently, $0.1 \mathrm{ml}$ iodine reagent $(1 \mathrm{~g}$ iodine and $4 \mathrm{~g}$ potassium iodide in $100 \mathrm{ml}$ water) was added to form a blue complex with the dissolved amylose present in the sample. The absorbance was read at $25^{\circ} \mathrm{C}$ and $600 \mathrm{~nm}\left(\mathrm{~A}_{1}\right)$. Another $0.04 \mathrm{~g}$ freeze dried sample was dissolved in $50 \mathrm{ml}$ of $0.40 \mathrm{M} \mathrm{KOH}$ to dissolve all the amylose presents in the sample completely, and centrifuged (10 min, $3000 \mathrm{~g}$ ) using a Beckman centrifuge. One ml supernatant was taken and neutralized with $0.045 \mathrm{M}$ $\mathrm{HCl}$. After adding $0.1 \mathrm{ml}$ iodine reagent, the absorbance was read at $25^{\circ} \mathrm{C}$ and $600 \mathrm{~nm}\left(\mathrm{~A}_{2}\right)$. The ratio $\mathrm{A}_{1}(0.15 \mathrm{M} \mathrm{KOH}) /$ $\mathrm{A}_{2}(0.40 \mathrm{M} \mathrm{KOH})$ was used as a measure for the degree of gelatinization of the sample.

\subsection{Determination of Total Phenolic Content}

The total phenolic content in PSP flour extract was determined by colorimetry method using Folin-Ciocalteu reagent assay as modified from Singleton and Rossi [16]. PSP flour extract $(1 \mathrm{ml})$ was mixed with $1 \mathrm{ml}$ of FolinCiocalteu's phenol reagent and allowed to react for 3 minutes. Then, $0.8 \mathrm{ml}$ of $7.5 \%(\mathrm{w} / \mathrm{v})$ sodium carbonate was added. The mixture was agitated and allowed to stand for further 30 minutes in the dark. The absorbance of PSP flour extracts and a prepared blank were measured at $765 \mathrm{~nm}$ using GENESYS UV-Visible spectrophotometer. The concentration of total phenolic compounds of preheat-treated PSP flour extracts was expressed as $\mathrm{mg}$ of tannic acid equivalents (TAE) per g dry weight of PSP flour using linear equation developed from tannic acid standard curved.

\subsection{Total Anthocyanin}

Total anthocyanin content was determined using the colorimetric $\mathrm{pH}$-differential method described by Lee et al. 
[17] using two buffer systems: potassium chloride buffer, $\mathrm{pH}$ $1.0(0.025 \mathrm{~mol} / \mathrm{L})(125 \mathrm{~mL}$ of $0.2 \mathrm{~mol} / \mathrm{L} \mathrm{KCl}$ and 375 of 0.2 $\mathrm{mol} / \mathrm{L} \mathrm{HCl})$ and sodium acetate buffer, $\mathrm{pH} 4.5(0.4 \mathrm{~mol} / \mathrm{L})$ ( $400 \mathrm{~mL}$ of $1 \mathrm{~mol} / \mathrm{L}$ sodium acetate, $240 \mathrm{~mL}$ of $1 \mathrm{~mol} / \mathrm{L} \mathrm{HCl}$ and $360 \mathrm{~mL}$ of water) with minor modification. One $\mathrm{mL}$ of extracted PSP flour was diluted in $4 \mathrm{~mL}$ of each buffer to achieve the absorbance readings at $520 \mathrm{~nm}$ or at $700 \mathrm{~nm}$ between 0.2 and 0.8 . The diluted samples were allowed to stand for $15 \mathrm{~min}$ at the dark room before the absorbance was read at 520 and $700 \mathrm{~nm}$ using a GENESYS UV-Visible spectrophotometer, with distilled water used as the blank.

Anthocyanin pigment concentration is expressed as cyanidin-3-glucoside equivalents as follows:

$$
\begin{aligned}
& \text { Anthocyanin pigment (cyanidin }-3- \\
& \text { glucoside equivalents } \mathrm{mg} / \mathrm{L})=100-\frac{A \times M W \times D F \times 1000}{\epsilon \times 1}
\end{aligned}
$$

Where:

$A$ is the absorbance of the sample calculated as: $\left(\mathrm{A}_{520}-\right.$ $\left.\mathrm{A}_{700}\right)_{\mathrm{pH} 1.0}-\left(\mathrm{A}_{520}-\mathrm{A}_{700}\right)_{\mathrm{pH}} 4.5$

MW is the molecular weight for cyanidin - 3-glucoside (449.2 $\mathrm{g} / \mathrm{mol})$.

$\mathrm{DF}=$ is the dilution factor

$\epsilon$ is the molar absorbance of cyanidin-3-glucoside (26900L/(cm x mol)

1 is cell path length $(1 \mathrm{~cm})$, and

1000 is the conversion factor from $\mathrm{g}$ to $\mathrm{mg}$

\subsection{DPPH (2,2-diphenyl-1-picrylhydrazyl) Radical Scavenging Assay of PSP Flour}

DPPH radical-scavenging activity of preheated PSP flour was determined using method described by Chung et al. [18] with minor modifications. Two $\mu \mathrm{L}$ of the anthocyanins extracted from the flour (as described in above procedure) were mixed with $2.0 \mathrm{~mL}$ of $2 \times 10^{-4} \mathrm{M} \mathrm{DPPH}$ in ethanol. The mixture was shaken vigorously and left in the dark at $25^{\circ} \mathrm{C}$ for $30 \mathrm{~min}$. The absorbance of mixture was read immediately at $517 \mathrm{~nm}$ using a GENESYS $10 \mathrm{~S} \mathrm{~S}$ UV-Visible spectrophotometer $\left(\mathrm{A}_{\text {sample }}\right)$. The mixture of $95 \%$ ethanol (2 $\mathrm{mL})$ and sample $(2 \mathrm{~mL})$ serve as blank $\left(\mathrm{A}_{\text {blank }}\right)$. The control solution was prepared by mixing ethanol $(2 \mathrm{~mL})$ and DPPH radical solution $(2 \mathrm{~mL})\left(\mathrm{A}_{\text {control }}\right)$. The ability of anthocyanin to scavenge DPPH radical or antioxidant activity was calculated by the following equation:

$$
\text { Scavanging Radical Activity }(\%)=100-\frac{A_{\text {sampel }}-A_{\text {blank }} \times 100}{A_{\text {control }}}
$$

In this study, the antioxidant property of the sweet potato flour was determined using only single method (DPPH assay). The decision was based on its availability and simplicity, furthermore Steed and Truong [19] reported that the antioxidant activities assayed by DPPH and ORAC (oxygen radical absorbance capacity) showed a significant correlation.

\subsection{Pasting Properties}

The pasting properties were measured using Brabender
Viscograph E (USB) Version 4.4.1. About $30 \mathrm{~g}$ moisture-free sample (db) was suspended in $470 \mathrm{ml}$ distilled water to prepare slurry in a large beaker. The suspension of the starch was mixed thoroughly and poured into the measuring bowl of the Brabender Viscograph. The test was run at a speed of seventy five (75) revolution per minute with a measuring range of $700 \mathrm{cmg}$. The temperature profile of the analysis was programmed to commence measurement at a temperature of $50^{\circ} \mathrm{C}$ with heating at the rate of $1.5^{\circ} \mathrm{C} / \mathrm{min}$ up to a temperature of $92^{\circ} \mathrm{C}$. The temperature of the sample was held constant for 15 minutes and then cooled at the rate of $1,5^{\circ} \mathrm{C} / \mathrm{min}$ to a temperature of $50^{\circ} \mathrm{C}$. This temperature was also held constant for ten (10) minutes. The parameters recorded from the curve include: the time, temperature and viscosity at the beginning of gelatinization, maximum viscosity, start of holding period, start of cooling period, end of cooling period, and at the end of final holding period as well as breakdown and set back viscosities. The measurements were done in two replications.

\subsection{SEM Analysis}

Granule micrographs were acquired using FEI Scanning Electron Microscope (SEM) type Inspect S50, EDAX AMETEK. Sample powder was placed in a double-sided carbon taped holder, then coated with Au-Pd using sputter coater (Emitech SC7620). The micrographs were obtained with an accelerating voltage of $10.00 \mathrm{kV}$.

\subsection{Experimental Design}

The experiment was arranged in a completely randomized block design with 4 replications, except for the pasting properties. The treatments were 6 levels of heating time of purple sweet potato, which were $0,15,30,45,60$, and $75 \mathrm{~min}$ at $90^{\circ} \mathrm{C}$. The data, except for pasting properties, were analyzed using Analysis of variance (ANOVA) to test the effect of the treatments, then further tested using Least Significant Difference Test at $\mathrm{p}<0.05$ to see significant differences among treatments. The pasting properties data were calculated for their standard deviation because we only did two replications, and therefore not valid for ANOVA analysis.

\section{Results and Discussion}

\subsection{Degree of Gelatinization}

The results showed that the length of preheating significantly affected the degree of gelatinization. The longer the preheating time had caused the higher degree of gelatinization (Table 1). This finding indicates that preheating treatment of PSP in a rotary drum cooker without addition of water before flouring process has caused partial gelatinization of the flour. Gelatinization is a phenomenon when starch granules are heated in water, gradually granules absorb water, swell and change in their structure. The extend of changes depends on some factors such as temperature, amount of water present, and agitation 
during heating [20].

Table 1. Degree of gelatinization of preheated PSP flour.

\begin{tabular}{ll}
\hline Preheating time (min) & Degree of gelatinization (\%) \\
\hline 0 & $14.9 \pm 0.2^{\mathrm{f}}$ \\
15 & $25.8 \pm 0.3^{\mathrm{e}}$ \\
30 & $28.1 \pm 0.3^{\mathrm{d}}$ \\
45 & $35.6 \pm 0.4^{\mathrm{c}}$ \\
60 & $39.0 \pm 0.4^{\mathrm{b}}$ \\
75 & $49.1 \pm 0.2^{\mathrm{a}}$ \\
\hline
\end{tabular}

Means within a column followed by different letters are significantly different at $(\mathrm{p}<0.05)$

\subsection{Total Phenolic Content}

All various length of preheating at $90^{\circ} \mathrm{C}$ induced reductions in total phenolic content. The initial phenolic content in fresh PSP was $74.3 \mathrm{mg} \mathrm{TAE} / 100 \mathrm{~g}$ dry matter, while those in preheated flour were between 15.3 and $34.6 \mathrm{mg} \mathrm{TAE} / 100 \mathrm{~g}$ (Table 2). The reduction of phenolic content could be attributed to polyphenol oxidase activity during heating. Takenaka et al. [21] claimed that the change in phenolic content during processing could be caused by degradation from the effects of heat, activity of polyphenol oxidase, and isomerization.

There were significant differences between the treatments $(\mathrm{P}<0.05)$, with loses occurring in the following order: without preheating $>$ preheating $15 \mathrm{~min}>$ preheating $30 \mathrm{~min}>45 \mathrm{~min}>$ $60 \mathrm{~min}>75 \mathrm{~min}$ at $90^{\circ} \mathrm{C}$ (Table 2). This result indicated that longer preheating time caused more phenolic retention. Cipriano et al. [22] reported that preheating treatment helped minimize polyphenol oxidase activity and increased polyphenolic recovery.

These results were in the range of total phenolic content of several sweet potato cultivars determined using Dennis reagent which were between 31.5 and $75.0 \mathrm{mg} / 100 \mathrm{mg}$ dry weight [23]. Padda [24] also reported the average total phenolic acid content in sweetpotato roots, stored at $15^{\circ} \mathrm{C}$ for 8 months, was 60.9 $\mathrm{mg} / 100 \mathrm{~g}$ fresh weight using the Folin-Denis reagent and 74.6 $\mathrm{mg} / 100 \mathrm{~g}$ fresh weight using the Folin-Ciocalteu reagent.

Table 2. Total phenolic content of preheated PSP flour.

\begin{tabular}{ll}
\hline Preheating (min) & Total Phenolic Content (mgTAE/100g dry weight)* \\
\hline 0 & $15.3 \pm 0.3^{\mathrm{f}}$ \\
15 & $22.0 \pm 0.3^{\mathrm{e}}$ \\
30 & $24.1 \pm 0.4^{\mathrm{d}}$ \\
45 & $24.3 \pm 0.4^{\mathrm{c}}$ \\
60 & $25.5 \pm 0.4^{\mathrm{b}}$ \\
75 & $34.7 \pm 0.5^{\mathrm{a}}$ \\
\hline
\end{tabular}

*total phenolic content of fresh purple sweet potato: $74.30 \mathrm{mgTAE} / 100 \mathrm{~g} \mathrm{db}$ Means within a column followed by different letters are significantly different at $(\mathrm{p}<0.05)$

\subsection{Total Anthocyanin Content}

Total anthocyanin contents of preheated SPS flour were between 50.40 and $63.15 \mathrm{mg}$ CEG (cyanidin- 3-glucoside equivalents)/100 g (Table 3), while those in fresh PSP was 64 $\mathrm{mg} \mathrm{CGE} / 100 \mathrm{mg} \mathrm{db}$. Anthocyanin of PSP flour preheated for 15,30 and 45 minutes were not significantly different. This finding indicated that heating shredded PSP at $90^{\circ} \mathrm{C}$ for 15 ,
30 or 45 minutes before flouring process did not significantly decrease anthocyanin in PSP flour. Kim et al. [25] reported that total content of anthocyanins in purple sweet potato only experienced slight decrease upon baking, furthermore they also reported that the main anthocyanin in purple-fleshed sweet potatoes are 3,5-diglucoside derivatives from cyanidin and peonidin, acylated with p-hydroxybenzoic acid, ferulic acid, or caffeic acid. Acylated anthocyanins are more stable during processing and storage [26], high heat and light [27] compared to those non acetylated.

Table 3. Total anthocyanin of preheated PSP flour.

\begin{tabular}{ll}
\hline Pre- heating time (min) & Total anthocyanin(mg/100g) \\
\hline 0 & $54.6 \pm 0.4^{\text {bcd }}$ \\
15 & $60.1 \pm 0.5^{\text {b }}$ \\
30 & $63.2 \pm 0.3^{\mathrm{a}}$ \\
45 & $58.6 \pm 0.3^{\text {abc }}$ \\
60 & $51.4 \pm 0.3^{\text {dd }}$ \\
75 & $50.4 \pm 0.5^{\mathrm{d}}$ \\
\hline
\end{tabular}

*total phenolic content of fresh purple sweet potato: $64,55 \mathrm{mg} / 100 \mathrm{~g} \mathrm{db}$ Means within a column followed by different letters are significantly different at $(\mathrm{p}<0.05)$

The anthocyanin contents of PSP flour in this study were lower compared to those of reported by Fan et al. [28], and Steed and Truong [19] where the anthocyanin contents were $158 \mathrm{mg} / 100 \mathrm{~g}$ (dry weight), and between $80-174,7 \mathrm{mg} / 100 \mathrm{~g}$ of fresh purple sweet potato respectively. Probably this was due to different varieties and extraction condition.

\subsection{DPPH Radical Scavenging Assay of PSP Flour}

The method of DPPH is reported to be a simple and rapid indirect assay for determining radical scavenging activity of plant sample [29] This method is based on the reaction that hydrogen-donating antioxidants reduce the color of DPPH free radical from violet to yellow DPHH-H, a non-radical form [30]. Table 4 shows DPPH radical-scavenging activity of the anthocyanins from preheated PSP flour. In general the radicalscavenging activities of antioxidants could be retained during preheating processed. The RSA of PSP flour preheated for 0 to 30 minutes were significantly lower than those of longer preheating treatments. This was probably polyphenol oxidase was still active during drying the flour, while those in longer preheating treatments has been inactive before drying the flour in an oven. The inactivation of polyphenol oxidase occurs at a relatively high temperature between 60 and $80^{\circ} \mathrm{C}$ [21]. The action of polyphenol oxidase has caused the reduction of total phenol, and this may have caused the decrease in RSA.

Table 4. DPPH radical scavenging assay of preheated PSP flour.

\begin{tabular}{ll}
\hline Treatment (min) & Radical Scavenging Activity (\%) \\
\hline 0 & $41.0 \pm 0.4^{\mathrm{c}}$ \\
15 & $46.7 \pm 0.3^{\mathrm{b}}$ \\
30 & $48.9 \pm 0.3^{\mathrm{b}}$ \\
45 & $53.7 \pm 0.2 \mathrm{a}^{\mathrm{b}}$ \\
60 & $52.2 \pm 0.3^{\mathrm{ab}}$ \\
75 & $62.4 \pm 0.4^{\mathrm{a}}$ \\
\hline
\end{tabular}

*RSA of fresh purple sweet potato was $71 \%$ 
Means within a column followed by different letters are significantly different at $(\mathrm{p}<0.05)$

\subsection{Pasting Properties}

The pasting properties of preheated PSP flour are presented in Table 5. In general, the beginning of gelatinization temperature did not change, except there was a slight decrease in preheated flour at $30 \mathrm{~min}$. The pasting properties of the flour decreased with the increased of heating duration. The original sweet potato flour showed higher peak (780 BU), breakdown (505 BU) and set back viscosities (227 BU) compared to those of preheated PSP flour.

Maximum viscosity shows the maximum swelling of the starch granule prior to disintegration, Liu et al. [31] claimed that peak viscosity is achieved when swelling and breakdown of the granules are in equilibrium stage. It also can be used as an indication of the viscous load likely to be encountered during mixing [32]. The decrease in the peak viscosity of preheated purple sweet potato flour could be attributed to the decrease in the degree of gelatinization. In addition, longer preheating duration had caused decrease in breakdown viscosity.

Table 5. Pasting properties of preheated PSP flour.

\begin{tabular}{|c|c|c|c|c|c|c|c|c|}
\hline \multirow{2}{*}{$\begin{array}{l}\text { Treatment } \\
\text { (Heating at } \\
\left.90^{\circ} \mathrm{C}\right)\end{array}$} & \multirow{2}{*}{$\begin{array}{l}\text { Start of } \\
\text { Gelatinization } \\
\text { temperature }\left({ }^{\circ} \mathrm{C}\right)\end{array}$} & \multicolumn{7}{|c|}{ VISCOSITY (BU) } \\
\hline & & $\begin{array}{l}\text { Maxi- } \\
\text { mum }\end{array}$ & $\begin{array}{l}\text { start of holding } \\
\text { period at } 90^{\circ} \mathrm{C}\end{array}$ & $\begin{array}{l}\text { start of cooling } \\
\text { period }\end{array}$ & $\begin{array}{l}\text { end of cooling } \\
\text { period }\end{array}$ & $\begin{array}{l}\text { End of final holding } \\
\text { period at } 50^{\circ} \mathrm{C}\end{array}$ & $\begin{array}{l}\text { Break- } \\
\text { down }\end{array}$ & Setback \\
\hline $0 \mathrm{~min}$ & $66.7 \pm 0.6$ & $780 \pm 0,8$ & $469 \pm 0.9$ & $321 \pm 0.7$ & $548 \pm 0.8$ & $571 \pm 0.5$ & $505 \pm 0.4$ & $227 \pm 0.4$ \\
\hline $15 \mathrm{~min}$ & $66.4 \pm 0.5$ & $557 \pm 1$ & $510 \pm 0.7$ & $349 \pm 0.6$ & $519 \pm 0.7$ & $527 \pm 0.3$ & $208 \pm 0.7$ & $170 \pm 0.5$ \\
\hline $30 \mathrm{~min}$ & $64.1 \pm 0.3$ & $590 \pm 1.2$ & $560 \pm 0.9$ & $392 \pm 1.0$ & $563 \pm 0.5$ & $574 \pm 0.3$ & $198 \pm 0.4$ & $171 \pm 0.9$ \\
\hline $45 \mathrm{~min}$ & $66.3 \pm 0.3$ & $688 \pm 1.5$ & $363 \pm 0.8$ & $222 \pm 0.9$ & $368 \pm 0.5$ & $375 \pm 0.4$ & $446 \pm 0.5$ & $146 \pm 0.6$ \\
\hline $60 \mathrm{~min}$ & $66.1 \pm 0.2$ & $643 \pm 2.0$ & $508 \pm 0.5$ & $319 \pm 0.7$ & $491 \pm 0.8$ & $503 \pm 0.5$ & $324 \pm 0.2$ & $172 \pm 0.6$ \\
\hline $75 \mathrm{~min}$ & $66.9 \pm 0.3$ & $547 \pm 2.1$ & $405 \pm 0.5$ & $263 \pm 0.5$ & $383 \pm 0.5$ & $381 \pm 0.5$ & $284 \pm 0.3$ & $120 \pm 0.5$ \\
\hline
\end{tabular}

Values are mean $\pm \mathrm{SD}$ of two replications

\subsection{SEM Analysis Results}

Scanning electron micrographs of native PSP flour and preheated flour show structural differences. Native flour contains starch granule which are round, spherical and surrounded by cell wall material (Figure 1). While in preheated SPS flour the granular characteristic partly changed and become more compact (Figure 2-6) due to partial gelatinization as a result of preheating. The change in granular structure may lead to the changes in starch functional properties and physiology function when starch is used for food and pharmaceutical purposes.

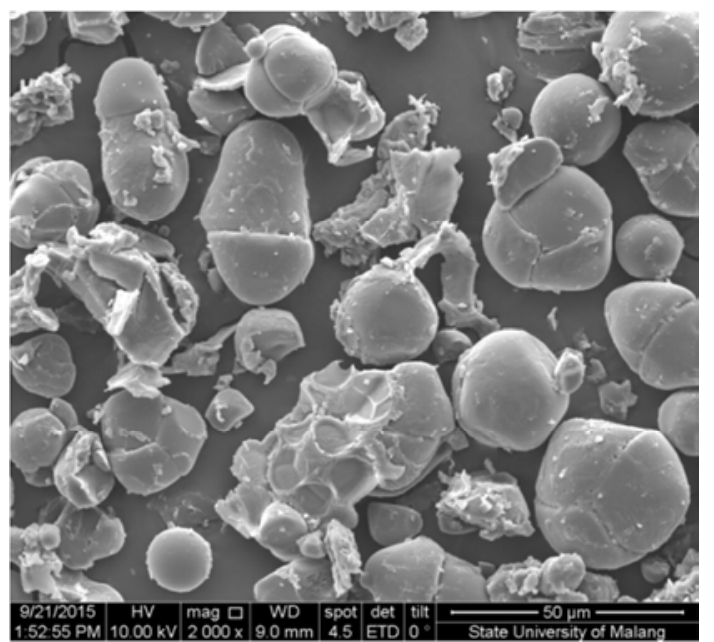

Figure 1. Native (Non Preheated) PSP Flour, 14.94\% Degree of Gelatinization.

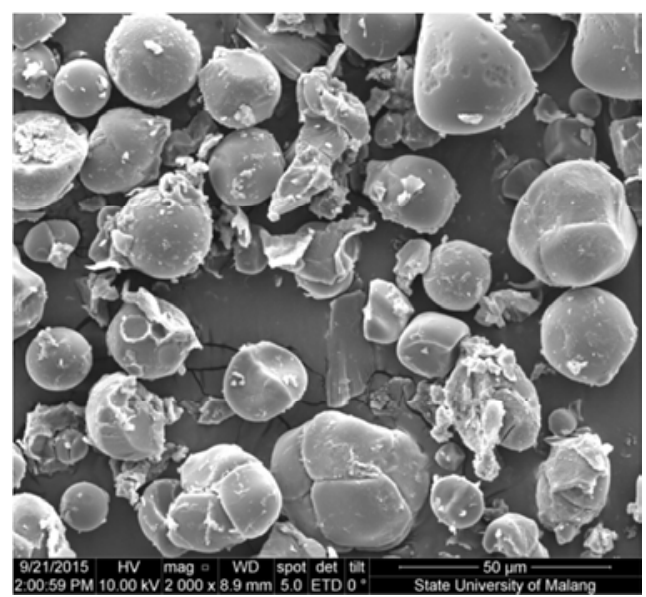

Figure 2. PSP Flour Preheated at $90^{\circ} \mathrm{C}$ for 15 minutes, $25.77 \%$ Degree of Gelatinization.

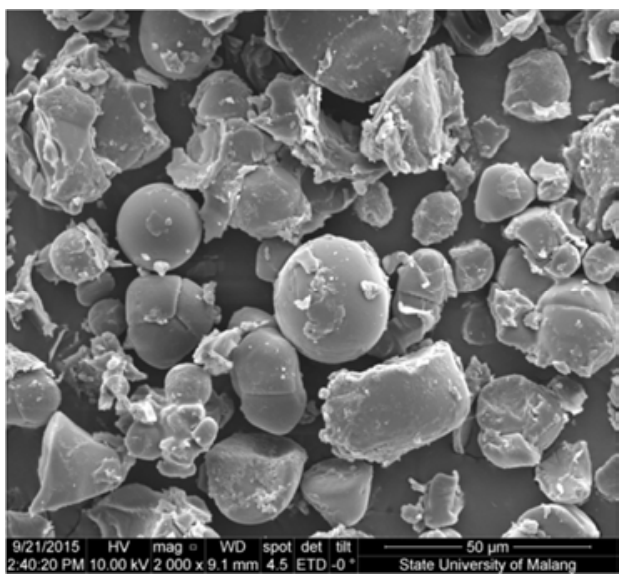

Figure 3. PSP Flour Preheated at $90^{\circ} \mathrm{C}$ for 30 minutes, $28.11 \%$ Degree of Gelatinization. 


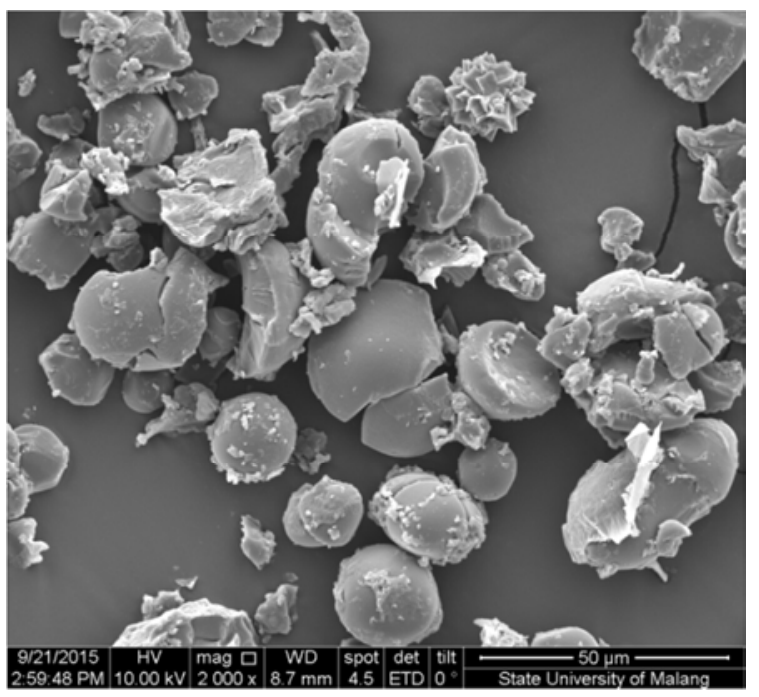

Figure 4. PSP Flour Preheated at $90^{\circ} \mathrm{C}$ for 45 minutes, $35.57 \%$ Degree of Gelatinization.

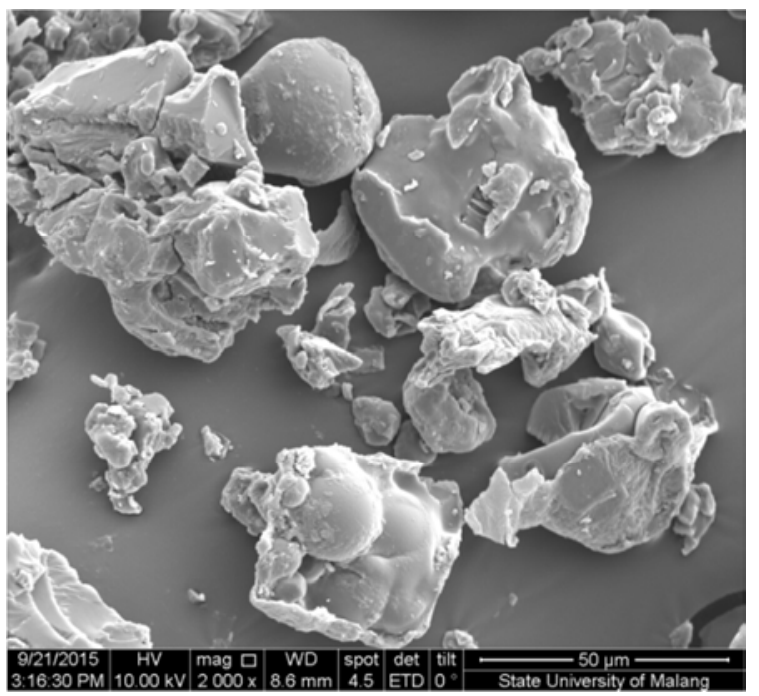

Figure 5. PSP Flour Preheated at $90^{\circ} \mathrm{C}$ for 60 minutes, $39.02 \%$ Degree of Gelatinization.

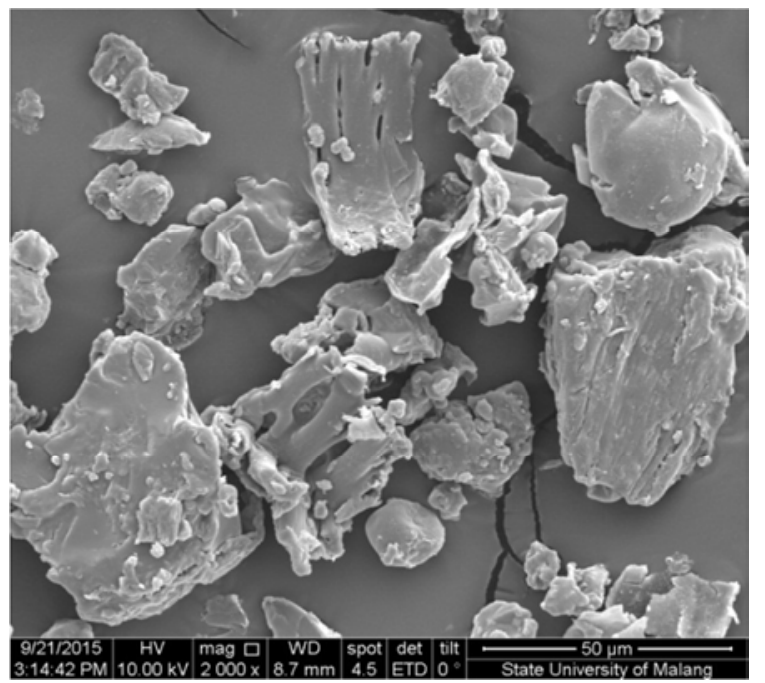

Figure 6. PSP Flour Preheated at $90^{\circ} \mathrm{C}$ for 75 minutes, $49.08 \%$ Degree of Gelatinization.

\section{Conclusion}

Preheating treatment of purple sweet potato flour caused an increase in degree of gelatinization, slight decreased in the start of gelatinization temperature, peak viscosity, and setback, but increased breakdown viscosity. Preheating treatment up to 75 min at $90^{\circ} \mathrm{C}$ of PSP before flouring could be used to preserve total phenolic compound, total anthocyanin and radical scavenging activity and change the granular structure of the flour. Thus preheating treatment could be used as a method for modifying and preserving functional properties to suit various applications of purple sweet potato flour.

\section{Acknowledgement}

The authors thank to The Ministry of Research, Technology and Higher Education of The Republic of Indonesia for funding this project through Competitive Research Grant (Hibah Bersaing, University of Lampung), with fund number:156/UN26/8/LPPM/2015.

\section{References}

[1] International potato Center, Centro Internacional de la Papa, 2016. Sweet Potato. http://www.cipotato.org/sweetpotato/). Downloaded at 02 January 2016

[2] Nurdjanah, S., J. Hook, J. Paton, and J. Paterson. 2013. Galacturonic acid content and degree of esterification of pectin from sweet potato starch residue detected using ${ }^{13} \mathrm{C}$ CP/MAS Solid State NMR. European Journal of Food Research \& Review. 3(1):16-37.

[3] Zhang, Z. C, G. H. Su, C. L. Luo, Y. L. Pang, L. Wang, X. Li, J. H. Wen and J. L. Zhang. 2015. Effects of anthocyanins from purple sweet potato (Ipomoea batatas L. cultivar Eshu No. 8) on the serum uric acid level and xanthine oxidase activity in hyperuricemic mice. Food \& Function 6: 3045-3055.

[4] Nagamine, R., S. Ueno, M. Tsubata, K. Yamaguchi, K. Takagaki, T. Hira, H. Hara and T. Tsuda. 2014. Dietary sweet potato (Ipomoea batatas L.) leaf extract attenuates hyperglycemia by enhancing the secretion of glucagon-like peptide-1 (GLP-1). Food \& Function, 5:2309-2316.

[5] Sugata, M., C. Y. Lin and Y. C. Shih. 2015. Anti-inflammatory and anticancer activities of Taiwanese purple-fleshed sweet potatoes (Ipomoea batatas L. Lam) extracts. BioMed Research International. http://dx.doi.org/10.1155/2015/768093.

[6] Hu, Y., L. Deng, J. Chen, S. Zhou, S. Liu, Y. Fu, C. Yang, Z. Loom and M. Chen. 2016. An analytical pipeline to compare and characterise the anthocyanin antioxidant activities of purple sweet potato cultivars. Food Chem. 194: 46-54.

[7] Truong, V. D., Z. Hu, R. L. Thompson, G. C. Yenco, K. V. Pecota. 2014. Pressurized liquid extraction and quantification of anthocyanins in purple-fleshed sweet potato genotypes. J. Food Comp. Anal. 26:96-103.

[8] Wu, X, G. R. Beecher, J. M. Holden, D. B. Haytowitz S. E. Gebhardt, and R. L. Prior. 2006. Concentration of anthocyanins in common foods in the United States and estimation of normal consumption. J. Agric. Food Chem. 54:4069-4075. 
[9] Kano, M., T. Takayanagi, K. Harada, K. Makino, and F. Ishikawa. 2005. Antioxidative activity of anthocyanins form purple sweet potato, Ipomoea batatas cultivar Ayamurasaki. Biosci Biotechnol Biochem. 69:979-988.

[10] Padda, M and D. H. Picha. 2008. Effect of low temperature storage on phenolic composition and antioxidant activity of sweetpotatoes. Postharvest Biology and Technology 47(2):176-180.

[11] Kader, F., B. Rovel, M. Girardin, and M. Metche. 1997. Mechanism of browning in fresh highbush blueberry fruit (Vaccinium corymbosum L.). Role of blueberry polyphenol oxidase, chlorogenic acid and anthocyanins. J. Sci Food Agr. 74:31-34.

[12] Cevallos-Casals, B. A., and L. Cisneros-Zevallos. 2004. Stability of anthocyanin-based aqueous extracts of Andean purple corn and red-fleshed sweet potato compared to synthetic and natural colorants. Food Chem. 86:69-77.

[13] Singh, S., C. S. Raina, A. S. Bawa and D. C. Saxena. 2005. Effect of heat-moisture treatment and acid modification on rheological, textural, and differential scanning calorimetry characteristics of sweet potato starch, J. of Food Sci. 70(6): E373-E378.

[14] Birch, G. G and R. J. Priestley. 1973. Degree of gelatinization of cooked rice. Starch 25:98-100.

[15] Baks, T., I. S. Ngene, J. J. G. van Soest, A. E. M. Janssen and R. M. Boom. 2007. Comparison of methods to determine the degree of gelatinization for both high and low starch concentrations. Carbohydr. Polym.67:481-490.

[16] Singleton, V. L. and J. A. Jr. Rossi. 1965. Colorimetry of total phenolics with phosphomolybdic-phosphotungstic acid reagents. Am J Enol Vitic. 16: 144-158.

[17] Lee, J., R. W. Durst and R. E. Wrolstad. 2005. Determination of total monomeric anthocyanin pigment content of fruit juices, beverages, natural colorants, and wines by the $\mathrm{pH}$ differential method: Collaborative Study. J. of AOAC Int. 88(5): 1269-1278.

[18] Chung, Y. C., S. J. Chen, and C. K. Hsu, 2005. Studies on the antioxidative activity of Graptopetalum paraguayense E. Walther. Food Chem. 91: 419-424.

[19] Steed, L. E., and V. D. Truong. 2008. Anthocyanin content, antioxidant activity and selected physical properties of flowable purple-fleshed sweetpotato purees. J. Food Sci. 73:215-221.

[20] Keetels, C. J. A. M.; van Vliet, T.; Walstra, P. 1996. Gelation and retrogradation of concentrated starch systems: 1. Gelation. Food Hydrocoll. 10 (3):343-353.
[21] Takenaka, M., K. Nakayama, S. Isobe, M. Murata. 2006. Changes in caffeic acid derivatives in sweet potato during cooking and processing. Biosci. Biotech. and Biochem. 70:172-177.

[22] Cipriano, P. A., L. Ekici, R. C. Barnes, C. Gomes and T. Talcott. 2015. Pre-heating and polyphenol oxidase inhibition impact on extraction of purple sweet potato anthocyanin. Food Chem. 180:227-234.

[23] Walter, W. M. and A. E. Purcell 1979. Evaluation of several methods for analysis of sweet potato phenolics. J Agric Food Chem. 27: 942-946.

[24] Padda, M. S. 2006. Phenolic composition and antioxidant activity of sweet potatoes [ Ipomoea batatas (L.) Lam]. Phd Dissertation, Louisiana State University.

[25] Kim, H. W., J. B. Kim, S. M. Cho, M. N. Chung, Y. M. Lee, S. M. Chu, J. H. Che, S. N. Kim, S. Y. Kim, Y. S. Cho, J. H. Kim, H. J. Park, and D. J. Lee. 2012. Anthocyanin changes in the Korean purple-fleshed sweet potato, Shinzaki, as affected by steaming and baking. Food Chem.130: 966-972.

[26] Giusti, M. M and R. E. Wrolstad. 2003. Acylated Anthocyanins from edible sources and their applicationsin foodsystems. Biochem. Eng. J. 14:217-225.

[27] Tsukui, A., T. Murakami, R. Shina and K Hayashi. 2002. Effect of alcoholic fermentation on the stability of purple sweet potato anthocyanin. Food Sci. and Tech. Res.8:4-7.

[28] Fan, G., Y. Han, Z. Gu and F. Gu. 2008. Composition and colour stability of anthocyanins extracted from fermented purple sweet potato culture. LWT - Food Sci. and Tech. 41 (8): 1412-1416.

[29] Kovela, I. I., T. A. Van Beek, J. P. H. Linssen, A. De Groot and L. N. Evstatieva. 2002. Screening of plant extracts for antioxidant activity: a comparative study on three testing methods. Phytochem. nalysis 13:8-17.

[30] Kumaran, A., and R. J. Kanukaran. 2005. Antioxidant and free radical scavenging activity of an aqueous extract of Coleus aromaticus. Food Chem. 97:109-114.

[31] Liu, Q., E. Donner, Y. Yin, R. L. Huang and M. Z. Fan, 2006. The physicochemical properties and in vitro digestibility of selected cereals, tubers, and legumes grown in China. Food Chem. 99: 470-477.

[32] Bao, J., Q. Shu, Y. Xia, C. Bergman and A. McClung. 2001. Effects of gamma irradiation on aspects on milled rice (Oryza sativa) end- use quality. J. of Food Quality 24: 327-336. 